BARRINGTON LECTURE 2010/2011

\title{
Terrorism, Tourism and FDI: Estimating a lower bound on the Peace Dividend in Northern Ireland
}

\author{
Cal Muckley ${ }^{1}$ \\ University College Dublin
}

(read before the Society, 24 March 2011)

\begin{abstract}
In this article we estimate the economic cost of terrorism with regard to foreign direct investment and tourism in Northern Ireland during periods extending from 1970 through to 2007. Previous studies which have estimated the economic cost of terrorism internationally have neglected Northern Ireland. As a result, we focus exclusively on the economic cost of terrorism in Northern Ireland, which has been significant. In particular, our analyses indicate that for those initiatives reliant on foreign direct investment as well as for the tourism sector, a fatality as a result of terrorism imputes a minimum economic cost of $£ 3.69$ million pounds sterling. Taken together, our findings indicate an economic lower bound on the cost of terrorism in Northern Ireland.
\end{abstract}

Keywords: terrorism, tourism, foreign direct investment, transfer function models

JELs: D74, H56, I31

\section{INTRODUCTION}

Should the Northern Ireland Assembly intervene with respect to terrorist activity in Northern Ireland ${ }^{2}$ If so, to what extent should resources be allocated to pursue a counter terrorist strategy of intervention? From an economic viewpoint, the response to these vitally important questions is straightforward. It relates to the relative expected costs of negotiation and/or alternatively nullifying the threat of terrorism as well as the expected economic cost of the terrorist activity itself. Specifically, if the expected economic cost arising from a terrorist campaign exceed the expected economic costs of successfully nullifying the threat of terrorism then the Northern Ireland Assembly should pursue a strategy to nullify that threat. As a result, an estimate of the expected economic costs of terrorist activity, from, for example, deterred tourist revenues and foreign direct investments (henceforth FDI), is a key issue with regard to informing an adequate response to these important questions. In this paper, we estimate a lower bound on the economic cost of terrorism with regard to tourism and FDI in Northern Ireland during recent decades. ${ }^{3}$

\footnotetext{
${ }^{1}$ Cal Muckley is a lecturer in finance and econometrics at the UCD Michael Smurfit Graduate Business School, Blackrock, Dublin, Ireland. His e-mail address is cal.muckley@ucd.ie. I am indebted to Jane McKenna and Gary Tedford in the Corporate Information Team at Invest Northern Ireland for data and advice on inward foreign direct investment to Northern Ireland and to Annmarie Montgomery at the Northern Ireland Tourist Board for data and advice on tourism activity in Northern Ireland. Also, an acknowledgement of thanks is due to Karen Wilson at the Department of Enterprise, Trade \& Investment for helpful advice and assistance regarding aspects of and the collection of these data. My thanks to Tim Besley, Don Bredin, Cathal Brugha, John Cotter, Kevin Denny, Orla Doyle, Colm Harmon, Ray Kinsella, Cormac Macfhionnlaoich and Cormac Ó'Comhraí for detailed comments on drafts of this article. This article is my stand-alone viewpoint and I remain responsible for errors and omissions.

${ }^{2}$ On 8 May 2007, the devolved Northern Ireland Executive was successfully restored with the creation of a new government under a power-sharing agreement between Nationalist and Unionist political parties. Devolution was completed on 12 April 2010 when policing and justice powers were transferred to the Northern Ireland Assembly from Westminster.

${ }^{3}$ Despite a marked decline in terrorist activity in Northern Ireland in the aftermath of the endorsement of the Good Friday Agreement and the largely successful process of decommissioning of firearms, ammunition and explosives there nonetheless remains a latent threat of significant terrorist activities. In December 2009, for example, the threat presented by dissident splinter groups, such as Oglaigh na hÉireann, the Continuity IRA and the Real IRA, had its highest official rating in over 5 years as indicated by Jonathan Evans (2010), the Director-General of the Security Service MI5. Specifically there is a substantial - a strong possibility of a - dissident threat in Britain and a severe - highly likely - dissident threat in Northern Ireland. As a result of heightened terrorist activities in Northern Ireland, significant additional resources have been devoted to the Police Service of Northern Ireland and MI5. Specifically, the Northern Executive have provided an additional $£ 45$ million to the PSNI to tackle
} 
It is widely accepted that a variety of factors influence the level of FDI to an economy including political and macroeconomic stability, regulatory issues and science, technology and innovation policy, the tailored skills and educational attainments of its labour force, as well as the effective taxation rate among others (Barry and O'Mahony 2004; and, Barry, 2007). As Northern Ireland is a small regional geographic area it is anticipated that its foreign capital inflows may exhibit significant sensitivities to political instability, i.e. terrorist activity, due, in particular, to the possibly undiversified nature of its investor base (Enders, 1996; Enders and Sandler, 2004; Busse, 2007; and, Jensen, 2008). In addition, FDI is an avenue of technology transfer and savings which are key determinants of economic growth in small economies exhibiting budget deficits (Coe and Helpman, 1994). In light of this likely sensitivity of FDI in the region to terrorism as well as the sensitivity of economic growth to FDI, it is particularly important to estimate the cost of terrorist activity with regard to foreign capital inflows to Northern Ireland. Turning to revenues from tourism, these revenues are also influenced by a variety of factors including the cost of living in the host economy, the pertinent foreign exchange rates, the health of the domestic and international economies, international trade, as well as the effects of weather among other factors (Northern Ireland Tourist Board's Tourism Barometer and Turner and Witt, 2001). As a matter of fact, comparable to trends in the Republic of Ireland (MacFeely, 2007), tourism revenues have increasingly contributed, in a significant fashion, to the economy of Northern Ireland. ${ }^{4}$ Nevertheless, due to the legacy of violence in Northern Ireland it is expected that the amount of receipts from tourism will have been depleted as a result of terrorist activities.

In the extant literature, a compelling negative relation has been established, from several complementary vantage points, with respect to the implications of terrorism for economic activity (Enders and Sandler 1991, 1996; Enders et al. 1992; Coshall 2003; Drakos and Kutan 2003; Abadie et al. 2003; Abadie and Gardeazabai 2005; Frey et al. 2007; and, Llorca-Vivero 2008). The corresponding direct costs to aggregate output, however, generally appear relatively low and short term (Hobijn, 2002; International Monetary Fund, 2001; Navarro and Spencer, 2001) in comparison with violent internal conflict and external war (Blomberg et al. 2004a) and natural disasters (Tavares, 2004). Indeed, Chen and Siems (2004) and Eldor and Melnick (2004) indicate that the effects of terrorism on the value of stocks appears relatively short-term, probably following from diversification effects which diminish the influence of risk on particular stocks. Nevertheless, high and persistent levels of terror, e.g. in Israel (Eckstein and Tsiddon, 2004) or the concentration of terror in specific regions, e.g. in the Basque country or in Palestine (Abadie and Gardeazabal, 2003; World Bank 2002, 2003, 2004) have a considerable impact. In addition, there is ample evidence that terrorism differentially impacts on specific sectors. For example, international capital inflows (Abadie and Gardeazabal, 2005 and Enders and Sandler, 1996) are likely to reduce materially as a result of terrorism and tourism is specifically vulnerable to terrorist attacks (Llorca-Vivero, 2008, Coshall, 2003, Drakos and Kutan, 2003; Enders, et al., 1992; and, Enders and Sandler, 1991).

Let us commence with a consideration of the cost of terrorism on tourism revenues. Enders and Sandler (1991) adopt a vector auto-regression methodology to examine tourism to Spain during the period 1970 to 1988 . Their findings indicate that, cumulatively, 140,000 tourists have been deterred from visiting Spain with respect to each individual terrorist incident. In the same vein, Coshall (2003) estimates, using an intervention function modeling technique, considerable abrupt negative impacts on the change in the numbers of United Kingdom air passengers travelling to various destinations, due to terrorist incidents including the Lockerbie air disaster (1988), and the Persian Gulf crisis (1990-1991). In addition, Llorca-Vivero (2008) specifies a cross-sectional gravity equation for tourism from the G-7 countries and finds significant implications, arising from terrorist incidents, on deviations from normal tourist flows. These findings, taken together, reflect a possibly important negative economic impact of international terrorist incidents on the performance of the transport industry, the tourism sector and arguably to the wider economy.

\footnotetext{
dissidents and the British treasury has provided an additional $£ 200$ million during the next 4 years with a view to accomplishing the same aim.

${ }^{4}$ A $61 \%$ increase in visitor revenue in Northern Ireland from $£ 220$ million in 1995 to $£ 354$ million in 2005 is documented in a House of Commons Report. In the same Report, Prof. Boyd at the School of Hospitality and Tourism Management at the University of Ulster indicated that tourism contributed to around 2-3\% of Northern Ireland's GDP. The Report is the House of Commons, Northern Ireland Affairs Committee, Tourism in Northern Ireland and its Economic Impact and Benefits, Third Report of Session 2006-07. The Report is collated with formal minutes, oral and written evidence.
} 
Enders et al. (1992) progress this line of argument considerably. They adopt transfer function modeling specifications to estimate the present value of the loss in tourism revenues between 1974 and 1988. Enders et al. (1992) present findings which indicate that Austria, Italy and Greece have lost $\$ 4.54, \$ 1.16$ and $\$ 0.77$ billion dollars in tourism revenues, in 1988 terms, as a result of terrorist incidents, respectively. In Europe as a whole, they indicate that total tourism revenues lost due to terrorist activities, during the period, amount to $\$ 16.15$ billion dollars, in 1988 terms. For comparison, total tourist revenues in Europe, in 1988, were $\$ 74.4$ billion dollars. To elaborate, the findings of Drakos and Kutan (2003) indicate that tourism revenues in continental Europe are much more heavily influenced by terrorism than country-by-country studies would imply as a result of substitution and simultaneously countervailing contagion effects.

Furthermore, terrorist activities within an economy (or in a neighbouring economy via the substitution or contagion implication of terrorism discussed in Drakos and Kutan, 2003) may materially affect the level of FDI to an economy (Enders and Sandler, 1996; and, Abadie and Gardeazabai, 2005). Enders and Sandler (1996), adopting a transfer function methodology, report that during the period from the mid 1970s to 1990, for each terrorist incident in Spain, there was, on average, a $\$ 23.82$ million dollar reduction in net FDI. This translates to a reduced annual FDI inflow of $13.5 \%$, on average, annually. Their findings, in regard to Greece, indicate a comparable reduction in FDI inflow of $11.9 \%$ annually. Abadie and Gardeazabai (2005) perform a cross-sectional analysis over 110 countries and provide corroborative results. Specifically, they estimate a robust negative effect on FDI across countries and modeling specifications also accounting for political, economic, legal, tax, operational and security factors. Frey et al. (2007) survey the literature on assessing the costs of terrorism and finds that while much of that literature neglects to go further than accounting for the number of terrorist incidents and casualties, a sizable amount of it aims to evaluate the economic implications of terrorism for tourism, FDI, savings and consumption, investment, stock prices, foreign trade and the urban economy as well as national income and growth. By way of an original empirical contribution to this debate, the authors specifiy a micro-econometric happiness function based on subjective wellbeing. ${ }^{5}$ Their findings suggest that people's utility losses may far exceed the purely economic consequences, and their estimates reveal a considerable loss of utility for residents in Northern Ireland relative to residents in the Republic of Ireland and the United Kingdom, as a result of terrorist incidents in Northern Ireland. Finally, Besley and Mueller (2009) provide a work-in-progress estimation of the impact of the peace process in Northern Ireland on Northern Ireland house prices. Their findings, adopting a Markov switching model where conflict and peace are treated as a latent state, reveal an interesting geographic locality specific negative relation between house prices and violence in Northern Ireland.

In the light of this discussion, what is the impact of terrorism on tourism and FDI revenues in Northern Ireland? Northern Ireland is a small geographic region which experienced more than 30 years of systematic terrorism until the mid 1990s with the re-emergence of dissident terrorist activities of late. Specifically, the contributions to the received literature have neglected to consider the economic implications, to tourism and FDI, of terrorist activities for Northern Ireland. This oversight probably arises due to the fact that Northern Ireland is a geographic region rather than a sovereign nation state. Data concerning tourism receipts and FDI that is examined in the extant literature is largely sourced in the International Monetary Fund's statistical archives, specifically the International Financial Statistics and Balance of Payments Statistics which do not include data on geographic regions. We seek to mitigate for the paucity of research undertaken on the economic implications of terrorism in Northern Ireland by availing of a novel data set from Invest Northern Ireland and the Northern Ireland Tourist Board. In addition, data with respect to terrorist activity are sourced at the U.S. Department of Homeland Security. All data examined in this article are detailed in the Appendix. In this article we adopt transfer function modeling techniques to estimate the implications of severe terrorist activities (i.e. fatalities) on FDI and revenues generated by tourism. Our findings indicate that for those initiatives reliant on foreign direct investment as well as for the tourism sector, a fatality as a result of terrorism imputes a minimum economic cost of $£ 3.69$ million pounds sterling. Taken together, our findings indicate an economic lower bound on the cost of terrorism in Northern Ireland.

This article is organised as follows. In Section 1, the importance of estimating a lower bound on the peace dividend in Northern Ireland is discussed and the novelty of our contribution is highlighted. In Section 2, the primary terrorist organisations in Northern Ireland are introduced and summary statistics regarding our whole data set are provided. In Section 3, our methodology is described and the corresponding findings are presented. In Section 4, we provide concluding remarks and avenues for future research are recommended.

\footnotetext{
${ }^{5}$ This function entails a life satisfaction approach, in which individual utilities are approximated by measurements of selfreported subjective well-being.
} 


\section{TERRORIST ORGANISATIONS AND PROXY VARIABLES}

We present details concerning the longevity, membership, objectives and targets of the primary terrorist organisations in Northern Ireland in Table 1 as well as an estimation of the minimum number of incidents, fatalities and injuries associated with these terrorist organisations in Table 2. It is evident that, according to the U.S. Department of Homeland Security, the Irish Republican Army is responsible for $73 \%$ (3280 of 4492 ) of the total number of terrorist incidents, 69\% (1004 of 1445) of the fatalities and 75\% (2277 of 3048) of the injuries inflicted on individuals. In summary, in Northern Ireland during the period 1970 through to 2007, the preponderance of illicit violence has been inflicted by the Irish Republican Army. ${ }^{6}$ Naturally, in this article, the allegiance of the perpetrator of the terrorist activities is of secondary interest. It is not specifically taken into account in the estimation of the economic cost of terrorism in Northern Ireland.

Table 1: Primary Terrorist Organisations in Northern Ireland: Characteristics, Targets and Objectives

\begin{tabular}{|c|c|c|c|c|}
\hline Organisation & Founded & Membership & Objectives & Targets \\
\hline $\begin{array}{c}\text { Catholic Reaction Force } \\
\text { (CRF) }\end{array}$ & 1983 & $\mathrm{n} / \mathrm{a}$ & $\begin{array}{l}\text { To discourage anti- } \\
\text { Catholic activity }\end{array}$ & Civilian \\
\hline $\begin{array}{l}\text { Continuity Irish } \\
\text { Republican Army } \\
\text { (CIRA) }\end{array}$ & 1986 & 50 & $\begin{array}{l}\text { Uniting Ireland under } \\
\text { Irish rule }\end{array}$ & Civilian, Police \\
\hline $\begin{array}{c}\text { Irish National Liberation } \\
\text { Army (INLA) } \\
\end{array}$ & 1974 & 50 & $\begin{array}{c}\text { An independent } \\
\text { communist Irish state }\end{array}$ & Civilian, Military \\
\hline $\begin{array}{l}\text { Irish Republican Army } \\
\text { (IRA) }\end{array}$ & 1917 & 1000 & $\begin{array}{c}\text { Ireland fully } \\
\text { independent of Great } \\
\text { Britain }\end{array}$ & Business, Military \\
\hline $\begin{array}{l}\text { Loyalist Volunteer Force } \\
\text { (LVF) }\end{array}$ & 1997 & 300 & $\begin{array}{l}\text { Separatist, Protect } \\
\text { Protestants }\end{array}$ & Civilians \\
\hline Official IRA (OIRA) & 1969 & inactive & $\begin{array}{c}\text { Marxist oriented } \\
\text { Republican } \\
\text { organisation }\end{array}$ & Military \\
\hline Orange Volunteers (OV) & $1970 \mathrm{~s}$ & 25 & $\begin{array}{l}\text { Protect Protestants, N. } \\
\text { Ireland in the UK }\end{array}$ & Business, Civilian \\
\hline $\begin{array}{c}\text { Real Irish Republican } \\
\text { Army (RIRA) }\end{array}$ & 1998 & 200 & $\begin{array}{c}\text { Unify Ireland's } 32 \\
\text { counties }\end{array}$ & Civilian, Military \\
\hline $\begin{array}{c}\text { Red Hand Defenders } \\
\text { (RHD) }\end{array}$ & 1998 & 20 & $\begin{array}{l}\text { Separatist, N. Ireland } \\
\text { remains in the UK }\end{array}$ & Civilian, Business \\
\hline \multicolumn{5}{|l|}{$\begin{array}{l}\text { Ulster Freedom Fighters } \\
\text { (UFF)/ }\end{array}$} \\
\hline $\begin{array}{c}\text { Ulster Defence } \\
\text { Association (UDA) }\end{array}$ & 1971 & 4000 & $\begin{array}{l}\text { Separatist, N. Ireland } \\
\text { remains in the UK }\end{array}$ & Civilian \\
\hline $\begin{array}{l}\text { Ulster Volunteer Force } \\
\text { (UVF) }\end{array}$ & 1966 & $\mathrm{n} / \mathrm{a}$ & $\begin{array}{l}\text { Separatist, N. Ireland } \\
\text { remains in the UK }\end{array}$ & Civilian, Paramilitary \\
\hline
\end{tabular}

Notes. Table 1 provides a description of the key terrorist organisations that have been present in Northern Ireland, at least temporarily, during the period 1971 through to 2008. The terrorist organization profiles data are sourced at the Memorial Institute for the Prevention of Terrorism, a training partner of the U.S. Department of Homeland Security. The Objectives are those alleged by the corresponding terrorist organisation. The Targets are the principal targets of the corresponding terrorist organisation. Neither the list of objectiver nor the list of targets are intended to be exhaustive.

\footnotetext{
${ }^{6}$ An important note of clarification is that Irish Republican Army targets are not exclusively non-civilian. In addition, it is worthwhile noting that these data naturally do not include violence that was perpetrated by the British Army (see e.g. the Lord Saville Report (2010) regarding the 'Bloody Sunday' incidents in Derry in January 1972) and the Royal Ulster Constabulary during these decades, as this violence was deemed lawful at the time when it occurred.
} 
Table 2: Characteristics of Incidents across Terrorist Organisations

\begin{tabular}{|c|c|c|c|}
\hline & & \multicolumn{2}{|c|}{ Decomposition of Incidents } \\
\hline Organisation & Incidents & Fatalities & Injuries \\
\hline $\begin{array}{c}\text { Catholic Reaction Force } \\
\text { (CRF) }\end{array}$ & 3 & 0 & 3 \\
\hline $\begin{array}{c}\text { Continuity Irish } \\
\text { Republican Army (CIRA) }\end{array}$ & 24 & 5 & 19 \\
\hline $\begin{array}{c}\text { Irish National Liberation } \\
\text { Army (INLA) }\end{array}$ & 190 & 69 & 121 \\
\hline $\begin{array}{l}\text { Irish Republican Army } \\
\text { (IRA) }\end{array}$ & 3280 & 1004 & 2277 \\
\hline $\begin{array}{l}\text { Loyalist Volunteer Force } \\
\text { (LVF) }\end{array}$ & 24 & 8 & 16 \\
\hline Official IRA (OIRA) & 38 & 16 & 22 \\
\hline Orange Volunteers (OV) & 54 & 0 & 54 \\
\hline $\begin{array}{c}\text { Real Irish Republican } \\
\text { Army (RIRA) }\end{array}$ & 268 & 30 & 238 \\
\hline $\begin{array}{l}\text { Red Hand Defenders } \\
\text { (RHD) }\end{array}$ & 12 & 6 & 6 \\
\hline $\begin{array}{l}\text { Ulster Freedom Fighters } \\
\text { (UFF) }\end{array}$ & 251 & 134 & 117 \\
\hline $\begin{array}{l}\text { Ulster Volunteer Force } \\
\text { (UVF) }\end{array}$ & 348 & 173 & 175 \\
\hline Aggregate & 4492 & 1445 & 3048 \\
\hline
\end{tabular}

Notes. Table 2 provides a description of the activities of the key terrorist organisations that have been present in Northern Ireland, at least temporarily, during the period 1971 through to 2008. All details are sourced in the Global Terrorism Database at the U.S. Department of Homeland Security, National Consortium for the Study of Terrorism and Responses to Terrorism at the University of Maryland. All presented figures are estimates of the minimum numbers of incidents, fatalities and injuries.

The summary statistics with respect to the arithmetic mean, its standard error, the minimum and the maximum of the proxy variables for the level of terrorist activity, tourism and $\mathrm{FDI}^{7}$ in Northern Ireland are presented in Table 3 and details are provided in the Appendix. It is noteworthy that on average there have been 26 fatalities per annum and some 72 terrorist incidents per annum during the period 1970 through to $2007 .^{8}$ In addition, there have been 1.12 million visits to Northern Ireland on average and these visits have generated (on the average) $£ 173.5$ million pounds sterling per annum of revenues for Northern Ireland when denominated in year 2000 prices. Turning to foreign capital inflows, the real FDI facilitated by Invest Northern Ireland (with regard to employment generating investment) is $£ 230.4$ million pounds sterling per annum on the average. The Table also comprises the results of the Phillips Perron (1988) unit root statistical test with respect to an appropriate differencing transformation, if required, such that the proxy variables are stationarity. Notably, all variables are found to be stationary if they are differenced. Subsequent empirical calculations in this article utilise appropriate transformations where required such that the proxy variables are stationary.

\footnotetext{
${ }^{7}$ Estimates of the net FDI stock are unavailable for the region of Northern Ireland.

${ }^{8}$ The data on terrorist activities adopted is sourced at the Global Terrorism Database of the United States Dept. of Homeland Security rather than from the updated and revised Sutton Index of Deaths (1994) as this latter index, inter alia, comprises deaths overseas as well as in Northern Ireland, following from terrorist activities related to Northern Ireland.
} 
Table 3: Summary Statistics

Panel A: Terrorist Activity

\begin{tabular}{|c|c|c|c|c|c|}
\hline Series & Mean & Std Error & Minimum & Maximum & PP Unit Root \\
\hline Fatalities & 26 & 31 & 0 & 87 & $-2.29\left[-7.22^{*}\right]$ \\
\hline Incidents & 72 & 69 & 4 & 214 & $-2.95^{*}\left[-8.78^{*}\right]$ \\
\hline Injuries & 87 & 88 & 0 & 270 & $-4.27^{*}[-$ \\
& & & & & $\left.12.79^{*}\right]$ \\
\hline $\begin{array}{c}\text { Fatalities \& } \\
\text { Injuries }\end{array}$ & 113 & 116 & 0 & 349 & $-3.65^{*}[-$ \\
\end{tabular}

Panel B: Tourism Revenues

\begin{tabular}{|c|c|c|c|c|c|}
\hline Series & Mean & Std Error & Minimum & Maximum & PP Unit Root \\
\hline $\begin{array}{c}\text { Domestic } \\
\text { Visits }\end{array}$ & $0.7 \mathrm{~m}$ & $0.24 \mathrm{~m}$ & $-0.4 \mathrm{~m}$ & $1.4 \mathrm{~m}$ & $-2.19\left[-8.28^{*}\right]$ \\
\hline $\begin{array}{c}\text { Real Domestic } \\
\text { Revenue }\end{array}$ & $71.4 \mathrm{~m}$ & $43.2 \mathrm{~m}$ & $7 \mathrm{~m}$ & $159 \mathrm{~m}$ & $-1.66\left[-10.27^{*}\right]$ \\
\hline Foreign Visits & $1.12 \mathrm{~m}$ & $0.49 \mathrm{~m}$ & $0.43 \mathrm{~m}$ & $2.11 \mathrm{~m}$ & $0.89\left[-6.93^{*}\right]$ \\
\hline $\begin{array}{c}\text { Real Foreign } \\
\text { Revenue }\end{array}$ & $173.5 \mathrm{~m}$ & $71.2 \mathrm{~m}$ & $67 \mathrm{~m}$ & $316.7 \mathrm{~m}$ & $0.72\left[-6.97^{*}\right]$ \\
\hline Real Total & $244 \mathrm{~m}$ & $91.2 \mathrm{~m}$ & $118.5 \mathrm{~m}$ & $446.2 \mathrm{~m}$ & $1.02\left[-6.10^{*}\right]$ \\
\hline
\end{tabular}

Panel C: Foreign Direct Investment

\begin{tabular}{|c|c|c|c|c|c|}
\hline Series & Mean & Std Error & Minimum & Maximum & PP Unit Root \\
\hline No. of Projects & 37 & 9 & 19 & 51 & $-2.61\left[-4.74^{*}\right]$ \\
\hline Jobs Promoted & 3351 & 1431 & 934 & 6584 & $-2.40\left[-4.77^{*}\right]$ \\
\hline $\begin{array}{c}\text { Jobs } \\
\text { Safeguarded }\end{array}$ & 2205 & 1209 & 204 & 5785 & $-7.23^{*}\left[-9.52^{*}\right]$ \\
\hline Real Assistance & $73.4 \mathrm{~m}$ & $40.6 \mathrm{~m}$ & $26.4 \mathrm{~m}$ & $148.7 \mathrm{~m}$ & $-2.88\left[-7.80^{*}\right]$ \\
\hline $\begin{array}{c}\text { Real Planned } \\
\text { Investment }\end{array}$ & $303.8 \mathrm{~m}$ & $134.4 \mathrm{~m}$ & $135.3 \mathrm{~m}$ & $554 \mathrm{~m}$ & $-3.26^{*}\left[-8.06^{*}\right]$ \\
\hline $\begin{array}{c}\text { Real } \\
\text { Investment }\end{array}$ & $230.4 \mathrm{~m}$ & $98 \mathrm{~m}$ & $105.7 \mathrm{~m}$ & $433.9 \mathrm{~m}$ & $-3.52^{*}\left[-8.20^{*}\right]$ \\
\hline
\end{tabular}

Panel D: Control Variables

\begin{tabular}{|c|c|c|c|c|c|}
\hline Series & Mean & Std Error & Minimum & Maximum & PP Unit Root \\
\hline $\begin{array}{c}\text { UK£ to US\$ } \\
\text { exchange rate }\end{array}$ & 0.57 & 0.097 & 0.39 & 0.86 & $-2.72\left[-5.92^{*}\right]$ \\
\hline $\begin{array}{c}\text { UK Marginal } \\
\text { Corporate Tax } \\
\text { Rate }\end{array}$ & 38.86 & 9.27 & 30 & 52 & $-0.82\left[-7.47^{*}\right]$ \\
\hline
\end{tabular}

Notes. Panels A, B, C and D correspond to the terrorist data, tourist, and foreign direct investment and control data examined in this article. Panels A and B extend over the full sample period from 1970 through to 2007 while Panel C extends from 1986/87 through to 2009/10. Panel D contains data on the UK£ to US\$ annual exchange rate in the period from 1970 through to 2007. It also contains data on the marginal corporate tax rate in the UK from 1986/87 through to 2009/10. In column 6, the PhillipsPerron (1988), PP, unit root test statistics are reported. The test statistics for each of the series in differences are reported in square brackets, while the test statistics with respect to levels are adjacent. A* indicates statistical significance at the $5 \%$ level. 


\section{ECONOMETRIC MODELLING AND EMPIRICAL FINDINGS}

Our matrices of static pairwise correlations are presented in Table 4. The matrices contain the terrorism related and tourism related stationary proxy variables in Panel A and the terrorism related and FDI related stationary proxy variables in Panel B. Of particular note in the Table are the negative correlations estimated between the innovations in the number of fatalities and the measurements of tourism and FDI activities. In this article, in our econometric work, we will specifically examine relations between innovations in the number of fatalities as a result of terrorist activities in Northern Ireland and innovations in the real revenues from overseas tourists denominated in 2000 prices and real FDI, also denominated in 2000 prices. These findings are presented in Table 5 and in Table 6.

Table 4: Correlation Matrices (See Appendix for Abbreviations)

Panel A: Terrorist Activity/Tourism

\begin{tabular}{|c|c|c|c|c|c|c|c|c|c|c|}
\hline Series & Inc. & $\Delta$ Fat. & Injuries & Fat. \& Inj. & $\Delta$ FV & $\Delta$ RFR & $\Delta$ DV & $\Delta$ RDR & $\Delta$ RT \\
\hline \multicolumn{9}{|c|}{} & \multicolumn{7}{|c|}{ Inc. } & 1.00 & & & & & & & & \\
\hline$\Delta$ Fat. & 0.02 & 1.00 & & & & & & & \\
\hline Injuries & 0.66 & 0.20 & 1.00 & & & & & & \\
\hline Fat. \& Inj. & 0.79 & 0.21 & 0.97 & 1.00 & & & & & \\
\hline$\Delta$ FV & -0.12 & -0.12 & -0.17 & -0.17 & 1.00 & & & & \\
\hline$\Delta$ RFR & 0.02 & -0.32 & -0.11 & -0.11 & 0.65 & 1.00 & & & \\
\hline$\Delta$ DV & -0.01 & -0.03 & -0.08 & -0.10 & -0.20 & 0.27 & 1.00 & & \\
\hline$\Delta$ RDR & -0.02 & 0.03 & 0.01 & -0.03 & -0.23 & 0.19 & 0.86 & 1.00 & \\
\hline$\Delta$ RT & -0.00 & -0.17 & -0.06 & -0.09 & 0.24 & 0.74 & 0.75 & 0.79 & 1.00 \\
\hline
\end{tabular}

Panel B: Terrorist Activity/Foreign Direct Investment

\begin{tabular}{|c|c|c|c|c|c|c|c|c|c|c|}
\hline Series & Inc. & $\Delta$ Fat. & Injured & Fat. \& Inj. & $\Delta$ NP & $\Delta$ JP & RA & Real Plan & RI \\
\hline \multicolumn{7}{|l|}{} & \multicolumn{5}{|l|}{} \\
\hline Inc. & 1.00 & & & & & & & & \\
\hline$\Delta$ Fat. & 0.05 & 1.00 & & & & & & & \\
\hline Injuries & 0.76 & 0.32 & 1.00 & & & & & & \\
\hline Fat. \& Inj. & 0.82 & 0.33 & 0.99 & 1.00 & & & & & \\
\hline$\Delta$ NP & -0.10 & -0.06 & -0.13 & -0.13 & 1.00 & & & & \\
\hline$\Delta$ JP & 0.09 & -0.44 & 0.10 & 0.09 & 0.42 & 1.00 & & & \\
\hline$\Delta$ RA & -0.02 & -0.55 & -0.08 & -0.09 & 0.28 & 0.67 & 1.00 & & \\
\hline RPI & 0.16 & -0.38 & 0.15 & 0.14 & 0.06 & 0.35 & 0.41 & 1.00 & \\
\hline RI & 0.13 & -0.39 & 0.10 & 0.09 & 0.04 & 0.30 & 0.37 & 0.99 & 1.00 \\
\hline
\end{tabular}

Notes. Panel A contains a sample pairwise contemporaneous correlation matrix relating to variables proxying for terrorist activity and tourism in Northern Ireland. Panel B contains a sample pairwise contemporaneous correlation matrix relating to these terrorist activity proxy variables as well as foreign direct investment proxy variables, as detailed in the Appendix. All series included in the correlation matrices are stationary according to the Phillips-Perron (1988) unit root test. 
To commence, we present the annual number of observations of fatalities as a result of terrorism as well as the annual amount of real tourism revenues in 2000 prices from overseas visitors during the period 1970 through to 2007 in Figure 1. It is apparent that there is a negative relation between these series, with the number of fatalities tending to decline over time and the real revenues from tourism tending to increase over time. In Figure 2 we present the annual number of observations of fatalities as a result of terrorism in Northern Ireland as well as real FDI to Northern Ireland. Once again, in this instance there is an apparent negative relation between the innovations in these series, as would be expected intuitively.

As an alternative to specifying a structural model to estimate the cost of terrorism in terms of revenue from tourists and FDI we specify and estimate transfer function models (Cauley and Iksoon, 1988; Enders and Sandler, 1996; and, Sloboda, 2003). In particular, we posit a transfer function model of the form

$$
y_{t}=\alpha_{1}+\sum_{i=1}^{p} \beta_{i} y_{t-i}+\sum_{i=0}^{q} \gamma_{i} x_{t-i}+\sum_{i=0}^{r} \delta \varepsilon_{t-i}
$$

and the $\alpha, \beta, \gamma$ and $\delta$ parameters correspond to constant coefficients. The variable $y_{t}$ corresponds to the level of real FDI (RI) or to the differential in real revenues stemming from overseas tourists (RFR), at time $t$. The exogenous proxy variable $x_{t}$ corresponds to the change in the number of fatalities, $\Delta F a t_{t}$, as a result of terrorist incidents at time $t$. Finally, $\varepsilon_{t}$ is a normal independent and identically distributed disturbance at time $t$. The coefficients $\gamma$ of the transfer function are of especial importance as they indicate the timing and magnitude of the impact of terrrorist activities on the level of real FDI (RI) or to the differential in real revenues stemming from overseas tourists (RFR).

We estimate a parsimonious transfer function model adopting Box-Jenkins (1976) techniques to inter-relate the innovations in the number of fatalities as a result of terrorism in Northern Ireland with real FDI to Northern Ireland. ${ }^{9}$ We present our findings in Table 5. In selecting an appropriate model we aim to adopt the parametrisation that minimises the Akaike and the Bayesian Schwartz Information criteria. ${ }^{10}$ In addition, the identified model should eliminate the autocorrelation in the residuals as indicated by the Ljung-Box (1978) $Q$ statistical test ${ }^{11}$ for autocorrelations in the residuals.

The empirical analyses indicate that the autoregressive moving average specification, $A R M A(0,1)$, appears to minimise the information criteria as well as simultaneously adequately purging the residuals of autocorrelation according to the Ljung-Box (1978) statistical test. Moreover, the Granger (1969) causality tests performed indicate that the lagged proxy variables do not improve the forecasting performance of the specified regressions. In short, there appears to be exclusively contemporaneous effects between these variables arising from innovations in the number of fatalities and affecting real FDI. This supports our adoption of a univariate $A R M A(0,1)$ transfer function model specification rather than a vector autoregression model specification with a view to modeling these processes. In contrast, it is notable that Enders and Sandler (1996) identify an 11 quarter lag in the response of Spanish net FDI to terrorist activities. Also noteworthy is the fact that there are no autoregressive terms in our estimated transfer function model. This is indicative of a lack of 'memory' in the evolution of FDI to Northern Ireland in regard to previous fatalities due to terrorism. Finally, as we have specified an adequate statistical model, we avail of this model to infer that the effect of a one unit increase in the number of fatalities, i.e. a death, due to terrorist activities, on real FDI is $£ 2.68$ million sterling in 2000 prices. This amount corresponds to $£ 3.36$ million sterling in 2009 prices.

\footnotetext{
${ }^{9}$ Allowing the terrorism proxy variable to follow an auto regressive moving average model, $D(L) x_{t}=E(L) \varepsilon_{x t}$, we initiate our model identification by constructing an appropriate cross correlogram

$D(L) y_{t} / E(L)=D(L) a_{0} / E(L)+D(L) A(L) y_{t-1} / E(L)+C(L) D(L) x_{t} / E(L)+B(L) D(L) \varepsilon_{t} / E(L)$. Specifically, the cross correlations of $\varepsilon_{x t}$ and the filtered $y$ values, $y_{f t}=D(L) y_{t} / E(L)$, reveal the transfer function. However, the estimated crosscorrelations are insufficiently informative and so information criteria are ultimately adopted to inform model identification.

${ }^{10}$ The object is to choose the set of parameters which minimises the value of the information criteria. Specifically, the Akaike and the Bayesian Schwarz Information criteria are calculated as $\ln \left(\hat{\sigma}^{2}\right)+\frac{2 k}{T}$ and $\ln \left(\hat{\sigma}^{2}\right)+\frac{k}{T} \ln T$ respectively. $\ln$ is the natural logarithm transformation, $\hat{\sigma}^{2}$ is an unbiased estimate of residual variance, $k$ is the number of parameters estimated and $T$ is the number of observations.

${ }^{11}$ The corresponding null hypothesis indicates that the test statistic $Q$ where $Q=T(T+2) \Sigma_{k=1}^{S} r_{k}^{2} /(T-k)$ is asymptotically $\chi^{2}$ distributed with $s$ degrees of freedom minus the number of estimated coefficients. In particular, the null hypothesis indicates that the $k$ values of the correlation coefficients are simultaneously equal to zero, $r_{k}=0$.
} 


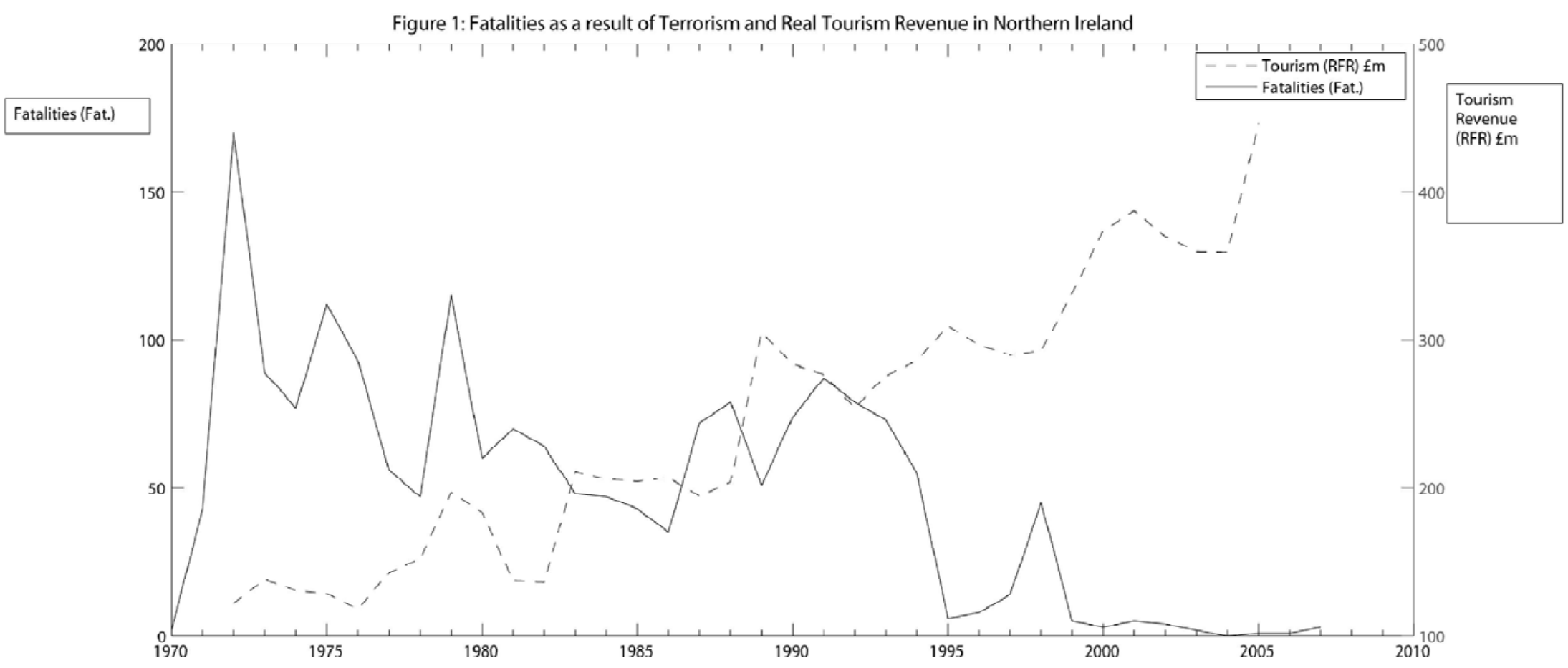




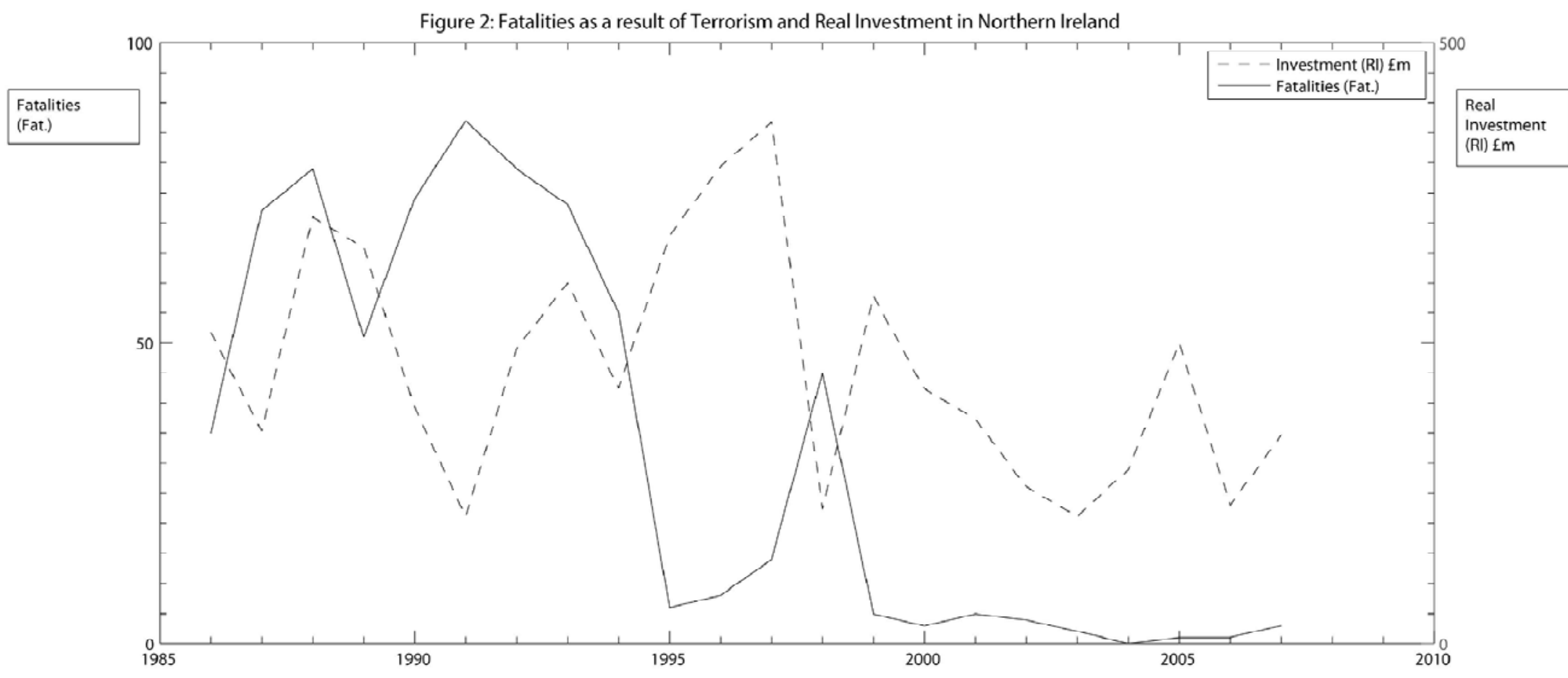


Table 5: Transfer Function Model for Terrorism and Foreign Direct Investment

Panel A: Transfer Function Model

\begin{tabular}{|c|c|c|c|c|c|}
\hline & & & $R I_{t}=221.38-2.68 \Delta$ Fat $_{t}+0.43 \varepsilon_{t}$ & & \\
\hline & $\alpha_{1}$ & $\gamma_{1}$ & $\delta_{1}$ & & \\
\hline ARMA(0,1) & $221.38^{*}$ & $-2.68^{*}$ & 0.43 & & \\
\hline$T-$ statistics & $(10.60)$ & $(2.30)$ & $(1.81)$ & & \\
\hline
\end{tabular}

Panel B: Diagnostic Tests

\begin{tabular}{|c|c|c|c|c|c|}
\hline & Akaike & Schwarz & & Akaike & Schwarz \\
\hline ARMA(0,1) & 9.17 & 9.32 & ARMA(1,0) & 9.19 & 9.34 \\
\hline ARMA(1,1) & 9.19 & 9.39 & ARMA(2,1) & 9.21 & 9.40 \\
\hline ARMA(1,2) & 9.30 & 9.55 & ARMA(2,2) & 9.54 & 9.82 \\
\hline & & & $\rho=3$ & $\rho=4$ & \\
\hline $\begin{array}{c}\text { Residual } \\
\text { Autocorrelations }\end{array}$ & $\rho=1$ & $\rho=2$ & -0.003 & 0.34 & \\
\hline & -0.004 & -0.281 & & & \\
\hline
\end{tabular}

\begin{tabular}{|c|c|c|c|c|c|}
\hline & Q-stat & Signif. & & & \\
\hline Ljung Box Q-stat & 5.06 & 0.17 & & & \\
\hline $\begin{array}{c}\text { Granger Causality } \\
\text { Tests }\end{array}$ & F-test & Signif. & & & \\
\hline $\begin{array}{c}H_{0}^{A}: \Delta F a t . \text { Lags } 1 \\
\text { to } 2=0\end{array}$ & 0.30 & 0.75 & & & \\
\hline $\begin{array}{c}H_{0}^{A}: R I . \text { Lags } 1 \text { to } 2 \\
=0\end{array}$ & 0.39 & 0.68 & & & \\
\hline $\begin{array}{c}H_{0}^{B}: \Delta F a t . \text { Lags } 1 \\
\text { to } 2=0\end{array}$ & 0.50 & 0.62 & & & \\
\hline $\begin{array}{c}H_{0}^{B}: R I . \text { Lags } 1 \text { to } 2 \\
=0\end{array}$ & 0.63 & 0.54 & & & \\
\hline
\end{tabular}

Notes. Panel A presents a parsimonious transfer function model, following Equation 1, inter-relating the differential in the number of fatalities as a result of terrorism and real investment in Northern Ireland during the period 1986/87 through to 2006/07. Panel B contains Akaike and Schwarz information criteria with regard to the appropriate order of the estimated transfer function model, the Ljung Box (1978) Q test to assess autocorrelations in the residuals of the model as well as Granger (1969) causality tests concerning the predictive power of the differential in the number of fatalities and the real investment variables. The Granger (1969) causality tests correspond to null hypotheses for Equation A with RI as a regressand and equation B with $\Delta F a t$. as a regresand. A * indicates statistical significance at the $5 \%$ level.

We also estimate a parsimonious transfer function model using Box-Jenkins (1976) techniques to inter-relate the innovations in the number of fatalities as a result of terrorism in Northern Ireland with innovations in real revenues from foreign tourists to Northern Ireland. We present our findings in Table 6. Again, in selecting an appropriate model we look to adopt the parametrisation that minimises the Akaike and the Bayesian Schwarz Information criteria. ${ }^{85}$ In addition, the identified model should eliminate the autocorrelation in the residuals as indicated by the Ljung-Box (1978) statistical test for autocorrelations in the residuals.

Our empirical findings indicate that the autoregressive moving average specification, $A R M A(0,[3,4])$, appears to minimise the information criteria and it simultaneously purges the residuals of autocorrelation according to the Ljung-Box (1978) statistical test. Moreover, the performed Granger (1969) causality tests indicate that the lagged

\footnotetext{
${ }^{85}$ Once again, in this instance, the cross correlations are insufficiently informative for model identification due to the uncertainty about the filtering function estimate.
} 
proxy variables do not improve the forecasting performance of the specified regressions, except in the $\Delta F a t$ equation where the null hypothesis that coefficients on lagged $\Delta F a t$ proxy variables are simultaneously equal to zero is rejected. In brief, while there are evident contemporaneous effects stemming from innovations in the number of fatalities as a result of terrorism to innovations in real revenues from foreign tourists in Northern Ireland, the predictive power of the various proxy variables is limited except for the presence of some evidence for autocorrelation in the innovations in the number of fatalities series. As this latter predictive power is neither supported in the previously presented Granger causality tests nor in our preliminary statistical modeling of the partial and auto-correlation functions we do not explicitly account for these possibly spurious statistical interdependencies here. Taken together, these overall findings support our adoption of a univariate $A R M A(0,[3,4])$ transfer function model rather than a vector autoregression model specification with a view to modeling these processes. Also noteworthy is the fact that there are no autoregressive terms in our transfer function model. This is indicative of a lack of 'memory' in the evolution of FDI to Northern Ireland in regard to previous fatalities due to terrorism. Finally, as we have specified an adequate statistical model we proceed to infer that the effect of a one unit increase in the number of fatalities, i.e. a death, due to terrorist activities, on real foreign tourist revenues is $£ 0.26$ million sterling in 2000 prices. This amount corresponds to $£ 0.33$ million sterling in 2009 prices. ${ }^{86}$

Table 6: Transfer Function Model for Terrorism and Tourism Revenue

Panel A: Transfer Function Model

\begin{tabular}{|c|c|c|c|c|}
\hline & \multicolumn{2}{|c|}{$\Delta R F R_{t}=3.57-0.26_{1} \Delta F a t_{t}-0.36 \varepsilon_{t-3}+0.57_{4} \varepsilon_{t-4}$} & & \\
& $\alpha_{1}$ & $\gamma_{1}$ & $\delta_{3}$ & $\delta_{4}$ \\
\hline ARMA(0, [3,4]) & 3.57 & $-0.26^{*}$ & $-0.36^{*}$ & $0.57^{*}$ \\
\hline$T$-statistics & $(1.02)$ & $(3.49)$ & $(2.83)$ & $(4.44)$ \\
\hline
\end{tabular}

Panel B: Diagnostic Tests

\begin{tabular}{|c|c|c|c|c|c|}
\hline & Akaike & Schwarz & & Akaike & Schwarz \\
\hline ARMA(2,2) & 5.98 & 6.16 & ARMA(0,2) & 5.98 & 6.11 \\
\hline ARMA(0,3) & 5.94 & 6.07 & $\operatorname{ARMA}(0,[3,4])$ & 5.86 & 6.04 \\
\hline
\end{tabular}

\begin{tabular}{|c|c|c|c|c|}
\hline $\begin{array}{c}\text { Residual } \\
\text { Autocorrelations }\end{array}$ & $\rho=1$ & $\rho=2$ & $\rho=3$ & $\rho=4$ \\
\hline & 0.08 & -0.18 & 0.02 & -0.13 \\
\hline
\end{tabular}

\begin{tabular}{|c|c|c|c|c|c|}
\hline & Q-stat & Signif. & & & \\
\hline Ljung Box Q-stat & 3.26 & 0.78 & & & \\
\hline
\end{tabular}

\begin{tabular}{|c|c|c|c|c|c|}
\hline Granger Causality Tests & F-test & Signif. & & & \\
\hline$H_{0}^{A}: \Delta$ Fat. Lags 1 to $2=0$ & 1.11 & 0.34 & & & \\
\hline$H_{0}^{A}: \Delta R F R$. Lags 1 to $2=0$ & 1.57 & 0.23 & & & \\
\hline$H_{0}^{B}: \Delta F a t$. Lags 1 to $2=0$ & $4.21^{*}$ & 0.03 & & & \\
\hline$H_{0}^{B}: \Delta R F R$. Lags 1 to $2=0$ & 0.22 & 0.81 & & \\
\hline
\end{tabular}

Notes. Panel A presents a parsimonious transfer function model, following Equation 1, inter-relating the differential in the number of fatalities as a result of terrorism and real revenues from foreign visitors in Northern Ireland during the period 1970 through to 2007. Panel B contains Akaike and Schwarz information criteria with regard to the appropriate order of the estimated transfer function model, the Ljung Box (1978) Q test to assess the autocorrelations in the residuals of the model as well as Granger (1969) causality tests concerning the predictive power of the differential in the number of fatalities and the real investment variables. The Granger (1969) causality tests correspond to null hypotheses for Equation A with $\triangle R F R$ as a regressand and equation B with $\triangle F a t$. as a regresand. A* indicates statistical significance at the $5 \%$ level.

\footnotetext{
${ }^{86}$ As noted in the Appendix, the methodology for calculating real revenues from foreign tourists alters in 2003. As a result we estimate the transfer function model specification until 2003 and we find qualitatively similar results. The findings are available from the author on request.
} 
In the Introductory Section of this article, it was indicated that various factors may influence foreign direct investment (Barry and O'Mahony 2004; and, Barry, 2007) and tourism revenues (Northern Ireland Tourist Board's Tourism Barometer and Turner and Witt, 2001), notwithstanding the effects of terrorism. While it is difficult to extend our model specification to explicitly account for all of these factors, we have extended the specification for innovations in real revenues from foreign tourists to include the UK pound to US dollar exchange rate innovations and we have extended the specification to explicate real FDI to include innovations in the the UK's marginal corporate taxation rate. Our findings, with respect to these extended specifications as detailed in Table 7, indicate that these incremental explanatory variables do not appear to significantly influence our original estimates of the Northern Ireland peace dividend. We leave the further extension of our set of control variables to future work.

Table 7: Transfer Function Models - Robustness Checks

\begin{tabular}{|c|c|c|c|c|c|}
\hline $\begin{array}{c}\text { Panel A: Transfer } \\
\text { Function Model - FDI }\end{array}$ & $\alpha_{1}$ & $\gamma_{1}$ & $\gamma_{2}$ & $\delta_{1}$ & \\
\hline ARMA(0,1) & $210.42^{*}$ & $-2.71^{*}$ & -44.22 & 0.33 & \\
\hline T-statistics & $(9.12)$ & $(2.34)$ & $(1.09)$ & $(1.35)$ & \\
\hline $\begin{array}{c}\text { Panel B: Transfer } \\
\text { Function Model - Tourism }\end{array}$ & & & & & \\
\hline & $\alpha_{1}$ & $\gamma_{1}$ & $\gamma_{2}$ & $\delta_{3}$ & $\delta_{4}$ \\
\hline ARMA(0,[3,4]) & 1.29 & $-0.26^{*}$ & -55.62 & $-0.44^{*}$ & $0.87^{*}$ \\
\hline T-statistics & $(0.32)$ & $(4.28)$ & $(1.56)$ & $(4.88)$ & $(7.34)$ \\
\hline
\end{tabular}

Notes. Panel A presents a parsimonious transfer function model, following Equation 1, inter-relating the differential in the number of fatalities as a result of terrorism and real investment in Northern Ireland during the period 1986/87 through to 2006/07. This model is extended to include alterations in the UK marginal corporate tax rate. Panel B presents a parsimonious transfer function model, also following Equation 1, inter-relating the differential in the number of fatalities as a result of terrorism and real revenues from foreign visitors in Northern Ireland during the period 1970 through to 2007. The model is extended to include the annual UK pound to US\$ exchange rate, observed January 1 of each year, sourced at World Market Reuters. The coefficient $\gamma_{2}$ corresponds to the control variable $\Delta \operatorname{Tax}_{t}$ in Panel A and it corresponds to the the control variable $\Delta U K U S_{t}$ in Panel B.

Taking our estimates of the economic costs of an incremental fatality as a result of terrorism in Northern Ireland together it is apparent that the implicit economic cost is at least $£ 2.94$ million pounds sterling. This amount is indicated in 2000 prices and it is equivalent to $£ 3.69$ million pounds sterling in 2009 prices. Furthermore, as a result of the average annual fatality rate, it is worthwhile noting that should we linearly extrapolate this estimate of the lower bound of the economic cost of terrorism it implies an annual average lower bound of the economic cost of terrorism of in excess of $£ 96$ million pounds sterling in 2009 prices.

\section{CONCLUSION}

In this article we have estimated a lower bound on the economic cost of terrorism with regard to FDI and tourism in Northern Ireland during periods extending from 1970 through to 2007. To the knowledge of the author no such estimate is otherwise available. In Northern Ireland, the estimation of the economic cost of terrorism is vitally important as it has implications for whether the Northern Ireland Assembly should pursue a strategy of intervention with respect to terrorist activity in Northern Ireland and, if so, to what extent it should allocate resources to pursue this strategy.

In particular, our statistical modelling of the economic cost of terrorism in Northern Ireland implies that we may infer that the effect of a one unit increase in the number of fatalities, i.e. a death as a result of terrorism in Northern Ireland, is at least £3.69 million UK Pound Sterling.

Turning to future research with regard to the economic cost of terrorism in Northern Ireland the findings presented here may be extended to include the economic cost of a fatality caused by terrorism to real domestic tourist revenues or real total tourist revenues rather than looking exclusively at real foreign tourist revenues. In addition, it may be worthwhile also looking at the economic cost of terrorist incidents rather than only those fatalities which have resulted from terrorist incidents. Finally, it may be valuable to consider the economic cost of fatalities as a result of terrorist incidents in Northern Ireland in terms of implications for employment in Northern Ireland. 


\section{References}

Abadie, A. and J. Gardeazabal, (2005) Terrorism and the world economy. Mimeo, Harvard University.

Abadie, A. and J. Gardeazabal, (2003) "The Economic Costs of Conflict: A Case Study of the Basque Country" American Economic Review 93(1) pp. 113-132.

Barry, F. (2007), "Foreign Direct Investment and Institutional Co-Evolution in Ireland".Scandinavian Economic History Review, Vol. 55(3), pp. 262-288.

Barry, F. and C. O'Mahony (2004), "Making Sense of the Data on Ireland's Inward FDI ". Journal of the Statistical and Social inquiry Society of Ireland Vol. XXXIV, pp. 28-65.

Besley, T. and H. Mueller (2004), "Estimating the Peace Dividend: The Impact of Violence on House Prices in Northern Ireland" Working Paper Series.

Blomberg, S.B., G. Hess and A. Orphanides (2004), "The Macroeconomic Consequences of Terrorism". Journal of Monetary Economics, Vol.20, No. 2, pp. 463-478.

Box, G.E.P. and G.M. Jenkins (1976), "Time Series Analysis, Forecasting and Control". San Francisco: Holden Day.

Busse, M. and Hefeker. C. (2007), "Political Risk, Institutions and Foreign Direct Investment".European Journal of Political Economy, Elsevier, Vol. 23(2), pp. 397-415.

Cauley, J. and Iksoon I. (1988), "Intervention Policy Analysis of Skyjackings and other Terrorist Incidents".American Economic Review, Vol. 78(2), pp. 27-31.

Chen, A.H. and T.F. Siems (2004), "The effects of terrorism on global capital markets" European Journal of Political Economy, Vol. 20(2), pp. 349-366.

Coe, David T and Elhanan Helpman (1995), "International R\&D Spillovers".European Economic Review, Vol. 39, pp. 859-887.

Coshall, J. (2003), "The Threat of Terrorism as an Intervention on International Travel Flows".Journal of Travel Research, Vol. 42(1), pp. 4-12.

Drakos, K. and A. M. Kutan (2003) Regional effects of terrorism on tourism in three Mediterranean countries. Journal of Conflict Resolution 47, pp. 621-641.

Eckstein, Z. and D. Tsiddon (2004) "Macroeconomic Consequences of Terror: Theory and the case of Israel". Journal of Monetary Economics Vol. 51(1), pp. 971-1002.

Eldor, R. and R. Melnik (2004) "Financial Markets and Terrorism". European Journal of Political Economy Vol. 20(2), pp. 367-386.

Enders, W. and Sandler, T. (1991), "Causality between transnational terrorism and tourism: the case of Spain." Terrorism 14: 49-58.

Enders, W. and Sandler. T. (1996), "Terrorism and Foreign Direct Investment in Spain and Greece".KYKLOS, Vol. 49(3), pp. 331-352.

Enders, W. and Sandler. T. (2004), "An economic perspective on transnational terrorism".European Journal of Political Economy, Vol. 20(2), pp. 301-316. 
Evans, J. (2010), "Address at the Worshipful Company of Security Professionals by the Director General of the Security Service". Internet sourced $16^{\text {th }}$ September, 2010:

https://www.mi5.gov.uk/output/the - threat - to - national - security. html.

Frey, B.S, Luechinger, S and A. Stutzer (2007), "Calculating Tragedy: Assessing the costs of Terrorism".Journal of Economic Surveys, Vol. 21(1), pp. 1-24.

Granger, C.W.J. (1969), "Investigating causal relations by econometric models and cross-spectral methods" Econometrica Vol. 37(3), 424-438.

Greene, W.H. (2003), "Econometric Analysis". Prentice Hall, $5^{\text {th }}$ Edition.

Hobijn, B. (2002), "What will homeland security cost?". Federal Reserve Bank of New York Economic Policy Review (November).

International Monetary Fund(2001), "How has September 11 influenced the Global Economy?" chapter 2 in World Economic Outlook 2001 Washington, DC: International Monetary Fund.

Jensen, N. (2008), "Political Risk, Democratic Institutions and Foreign Direct Investment".Journal of Politics, Vol. 70, pp. 1040-1052.

Llorca-Vivero, R. (2008), "Terrorism and International Tourism: New Evidence".Defence and Peace Economics, Vol. 19(2), pp. 169-188.

Ljung, G.M. and G.E.P. Box. (1978), "On a Measure of Lack of Fit in Time Series Models".Biometrika, Vol. 67(2), pp. 297-303.

MacFeely, S. (2007), "A Statistical Profile of Irish Domestic Tourism, 2000-2005".Journal of the Statistical and Social inquiry Society of Ireland, Vol. XXXVI, pp. 126-166.

Navarro P. and A. Spencer (2001), "September 2001: Assessing the Cost of Terrorism".Milken Institute Review, Vol. 2, pp. 423-433.

Phillips, P.C.B. and P. Perron. (1988), "Testing for a Unit Root in Time Series Regressions".Biometrika, Vol. 65(1), pp. 335-346.

Prieto-Rodriguez, J., Rodriguez, J.G., Salas, R. and J. Suarz-Pandiello (2008), "Understanding, quantifying and modeling the terrorist threat".Journal of Policy Modeling, Vol. 31(5), pp. 803-817.

Sutton, M. (1994), "An Index of Deaths from the conflict in Ireland 1969-1993". Beyond the Pale Publications, ISBN 0-9514229-4-4.

Tavares, J. (2004), "The Open Society Assesses its Enemies: Shocks, Disasters and Terrorist Attacks". Journal of Monetary Economics, Vol. 51(5), pp. 1039-1070.

Turner, L.W. and S. F. Witt. (2001), "Factors influencing demand for international terrorism: tourism demand analysis using structural equation modelling, revisited".Tourism Economics IP Publishing Ltd., Vol. 7(1), pp. 21-38.

World Bank. (2004), "Four Years - Intifada, Closures and Palestinian Economic Crisis An Assessment".Washington, DC: World Bank. 
5 APPENDIX: A DESCRIPTION OF OUR DATA

\begin{tabular}{|c|c|}
\hline Series & Description \\
\hline \multicolumn{2}{|l|}{ Terrorism } \\
\hline Incidents [Inc] & The number of terrorist incidents. \\
\hline Fatalities [Fat] & The number of fatalities as a result of terrorist incidents. \\
\hline Injuries [Inj] & The number of individuals injured as a result of terrorist incidents. \\
\hline Fatalities \& Injuries & The summation of fatalities and the number of individuals injured. \\
\hline \multicolumn{2}{|l|}{ [Fat \& Inj] } \\
\hline & $\begin{array}{l}\text { Source: Global Terrorism Database at the U.S. Department of Homeland } \\
\text { Security, National Consortium for the Study of Terrorism and Responses } \\
\text { to Terrorism at the University of Maryland }\end{array}$ \\
\hline \multicolumn{2}{|r|}{ 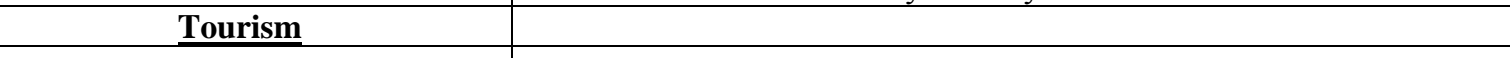 } \\
\hline Domestic Visits [DV] & The number of domestic visitors. \\
\hline Real Domestic Revenue [RDR] & $\begin{array}{l}\text { Real domestic revenue in millions of UK Pound Sterling, } 2000 \text { prices. } \\
\text { The 2005-08 'domestic' figures avail of methodological changes and } \\
\text { hence are not strictly comparable with previous figures. }\end{array}$ \\
\hline Foreign Visits [FV] & The number of out of state visitors. \\
\hline Real Foreign Revenue [RFR] & $\begin{array}{l}\text { Real foreign revenue in millions of UK Pound Sterling, } 2000 \text { prices. The } \\
2003-08 \text { 'foreign' figures avail of methodological changes and hence are } \\
\text { not strictly comparable with previous figures. }\end{array}$ \\
\hline \multirow[t]{2}{*}{ Real Total Revenue [RT] } & $\begin{array}{l}\text { Real total revenue in millions of UK Pound Sterling, } 2000 \text { prices. This is } \\
\text { the summation of real domestic and real foreign revenue. }\end{array}$ \\
\hline & $\begin{array}{l}\text { Sources: Northern Ireland Tourist Board and the Office for National } \\
\text { Statistics UK }\end{array}$ \\
\hline \multicolumn{2}{|l|}{ Foreign Direct Investment } \\
\hline Jobs Promoted [JP] & The number of jobs it is expected will be created by the projects. \\
\hline Jobs Safeguarded [Jobs Safe] & $\begin{array}{l}\text { The number of jobs it is expected would have been lost if projects had } \\
\text { not been supported. }\end{array}$ \\
\hline No. of Projects [NP] & The number of projects undertaken by Invest Northern Ireland clients. \\
\hline Real Assistance [RA] & $\begin{array}{l}\text { The real total assistance offered in millions of UK Pound Sterling, } 2000 \\
\text { prices. }\end{array}$ \\
\hline Real Planned Invest. [RPI] & $\begin{array}{l}\text { The real planned investment (including assistance) offered in millions of } \\
\text { UK Pound Sterling, } 2000 \text { prices. }\end{array}$ \\
\hline \multirow[t]{2}{*}{ Real Invest. [RI] } & $\begin{array}{l}\text { The real planned investment (excluding assistance) in millions of UK } \\
\text { Pound Sterling, } 2000 \text { prices. }\end{array}$ \\
\hline & $\begin{array}{l}\text { Sources: Invest Northern Ireland, Corporate Information Team (was the } \\
\text { Industrial Development Board from 1986/87 to 2001/02) and the Office } \\
\text { for National Statistics UK }\end{array}$ \\
\hline \multicolumn{2}{|l|}{ Control Variables } \\
\hline $\begin{array}{l}\text { UK pound to US\$ exchange rate } \\
\text { [UKUS] }\end{array}$ & Annual Exchange Rate, observed January 1 each year \\
\hline Corporate Tax Rate [Tax] & Marginal UK Corporate Tax Rate \\
\hline & Sources: World Market Reuters and Her Maje \\
\hline
\end{tabular}

Notes. The set of observations on terrorist activity extend from 1970 through to 2007 inclusive. The set of observations on tourism revenues extend from 1959 through to 2009 and the set of observations on foreign direct investment extend from the financial year 1986/87 through to 2009/2010. Foreign direct investment measurements relate to the job generating investments of Invest Northern Ireland clients. All observations contained in the Appendix are observed annually and relate exclusively to Northern Ireland as detailed above. 


\section{VOTE OF THANKS PROPOSED BY JOE DURKAN, ESRI}

This paper extends to the Northern Ireland context some of the work undertaken in other countries on the economic costs of terrorism. The focus of the paper is on FDI and tourism. Figures 1 and 2 show clearly the correlation between FDI and tourism and fatalities from terrorism and the paper is about estimating the relationships. The conclusion is that a death will affect FDI by $£ 2.68$ million and tourist revenue by $£ 0.26$ million, giving a total of $£ 2.94$ million at 2000 prices. I have no problems with the econometrics, beyond thinking that given the nature of the hypothesis and the data, OLS might have been sufficient. My concerns relate to the notion of the economic cost of the conflict and to a lesser extent what the results imply for investment.

First, the focus on FDI and tourism assumes that a reduction in the level of both is an economic cost equal to their sum. A $£$ in extra tourism is not the same as a $£$ in extra investment if we are trying to measure impacts. The question that must be asked is who bears the cost? Is it the firms discouraged by terrorism, who may go elsewhere, the potential employees of the firm, or those involved in the actual investment project (construction etc) where FDI is considered? Are we trying to get some measure of GDP both currently and in the future? If it is the effect on the domestic economy then we need to do more than measure just the direct effect. We must also consider the likelihood that projects might fail, and the costs associated with attracting FDI, both of which we have some information on. The DeLorean Project was very big both in terms of investment, and public financing and failed. Even though this project was undertaken outside the time frame of the data considered it is cautionary. What was the economic benefit of similar projects that failed, and more pertinently, the effect this has on the measure of the cost to FDI of a death? Why look at FDI and not Private investment in total. Tourism is obviously different, but it is still worthwhile to ask what the benefit of tourism to Northern Ireland is. Clearly it is not just the measure of expenditure. What is the direct contribution in GDP terms?

Second, I am uncomfortable with the exclusion of the value of the lives lost through the conflict. We are always reluctant to place a value on life, but it is implicitly done in public decision making, by not correcting "black spots" on roads, by requiring safety features on cars, by the amount that is spent on different forms of healthcare and so on. In the extra resources devoted to security in Northern Ireland there was a recognition that the issue was one of lives lost, injury to persons and personal tragedies. These extra resources are also a cost, as there were alternative uses for them. Much of these resources came from Britain as did the funding for reconstruction. An obvious extension of this work is to look at the extent to which the whole economy was affected by terrorism and the possible impact of external funding by Britain on its duration.

Third, it seems unlikely that real planned investment would be responsive to the number of deaths from terrorism - it is more plausible to think that there may be delays to starts, or that government might weigh in with more assistance. The paper forced me to think of these issues again and accordingly I have no hesitation in proposing a vote of thanks for the author. 